\title{
Conserving the African wild dog Lycaon pictus. I. Diagnosing and treating causes of decline
}

\author{
Rosie Woodroffe and Joshua R. Ginsberg
}

\begin{abstract}
The African wild dog Lycaon pictus has declined dramatically over the past 30 years. Formerly distributed throughout sub-Saharan Africa, today c. 5000 wild dogs remain in total, mostly in southern and eastern Africa. Wild dogs' decline reflects the expansion of human populations and the associated fragmentation of habitat available to wildlife. Because wild dogs live at very low densities, even 'fragments' covering thousands of square kilometres may not support viable populations. Furthermore, packs often range beyond the borders of reserves, so even nominally protected populations are often subject to persecution, road accidents, snaring and disease contracted from domestic dogs. Such edge effects mean that reserves smaller than $c .10,000 \mathrm{sq} \mathrm{km}$ will provide only incomplete pro-
\end{abstract}

tection. The highest priority for wild dog conservation, therefore, is to maintain and promote the contiguity of areas available to wildlife. Establishing cross-border parks and buffer zones, and encouraging game ranching on reserve borders, will all be beneficial. In smaller areas, protecting wild dogs requires that edge effects be mitigated by: (i) working with local farmers to limit persecution; (ii) controlling snaring; (iii) routing roads carrying high-speed traffic away from wildlife areas; and (iv) minimizing contact between wildlife and domestic dogs. Most of these measures will also benefit other wildlife.

Keywords Carnivore conservation, edge effects, predator management, protected areas, wildlife disease.

\section{Introduction}

There can be no doubt that African wild dogs Lycaon pictus have declined over the last century, and this decline has accelerated in the last 30 years (Woodroffe et al., 1997). Once distributed throughout most of subSaharan Africa, wild dog populations have now disappeared from most countries in West and central Africa, and are highly fragmented in the East and South (Fig. 1). Today, Africa's wild dog population numbers 30005000 (Table 1), and the species is listed as Endangered by IUCN (1996). Most populations outside-and sometimes inside-protected areas are probably still declining. Wild dogs are rare compared with other high-profile species in Africa: there are about the same number of wild dogs as there are black rhinos Diceros bicornis (c. 3000; Cumming et al., 1990), and far fewer wild dogs than African elephants Loxodonta africana (minimum 290,000; Said et al., 1995) (Plates 1 and 2).

Rosie Woodroffe (corresponding author) Department of Biological Sciences, University of Warwick, Coventry CV4 7AL, UK. Tel: +44 (0)1203 524618; fax: + 44 (0)1203 524619;

e-mail: r.b.woodroffe@warwick.ac.uk

Joshua R. Ginsberg Wildlife Conservation Society, 2300 Southern Bvd, Bronx, NY 10460-1099, USA. Tel: + 1718220 5884; fax: + 1 718364 4275; e-mail: jginsberg@wcs.org

Received 18 May 1998. Accepted 1 October 1998
The decline of wild dog populations reflects the geographical pattern of human population growth; today, wild dogs persist only in countries with relatively low human densities (Fig. 2). Although this points to the ultimate cause of local extinctions, setting priorities for wild dog conservation demands a more detailed analysis of their decline. In this paper, we refine previous analyses (Fanshawe et al., 1991; Woodroffe et al., 1997), using historical records and field data to identify factors that have contributed to past extinctions of wild dog populations, and those that might cause remaining populations to decline further or disappear. Only by evaluating the impact of each threat is it possible to determine the management strategies most likely to halt or reverse wild dogs' decline.

\section{Wild dog ecology and behaviour}

Identifying the threats faced by wild dogs depends upon a detailed understanding of their ecology and behaviour. Wild dogs are never common; population density averages 24 adults $1000 \mathrm{sq} \mathrm{km} \mathrm{(} n=7$ studies; Woodroffe et al., 1997). For comparison, wild dogs are usually outnumbered by lions Panthera leo by a factor of about three (range 2.3-20.9), and by spotted hyaenas Crocuta crocuta by a factor of about 10 (range 2.3-122; Creel \& Creel, 1996; Woodroffe et al., 1997). As a result of this low density, even the largest protected areas 
support only small populations. Kruger National Park, for example, covers $22,000 \mathrm{sq} \mathrm{km}$ but contains fewer than 400 wild dogs (Maddock \& Mills, 1994); most populations are substantially smaller than this, numbering just a few packs (Woodroffe et al., 1997).

Wild dogs are coursing predators, chasing their prey over distances of up to $4 \mathrm{~km}$ (Fanshawe \& FitzGibbon, 1993; Creel \& Creel, 1995). Their principal prey are medium-sized antelopes such as impala Aepyceros melampus, wildebeest Connochaetes taurinus and kudu Tragelaphus strepsiceros (Woodroffe et al., 1997). Livestock are taken in some areas, but this is a fairly rare occurrence (Fanshawe, 1989; Fuller \& Kat, 1990; Bowler, 1991; Rasmussen, 1996).

Wild dogs range very widely: each pack uses an area of about $650 \mathrm{sq} \mathrm{km}$ on average $(n=45$ packs, range 150-2460 sq km; Fuller \& Kat, 1990; Fuller et al., 1992a; Creel \& Creel, 1995), much greater than would be predicted from their energetic requirements (Gittleman \& Harvey, 1982). Travelling so widely, many packs using protected areas also range extensively outside reserve borders. Dispersing groups move still further; they have been followed for hundreds of kilometres (Fuller et al., 1992b), and are occasionally reported from countries such as Uganda and Swaziland, where there have been no resident populations for many years (Woodroffe et al., 1997). Packs

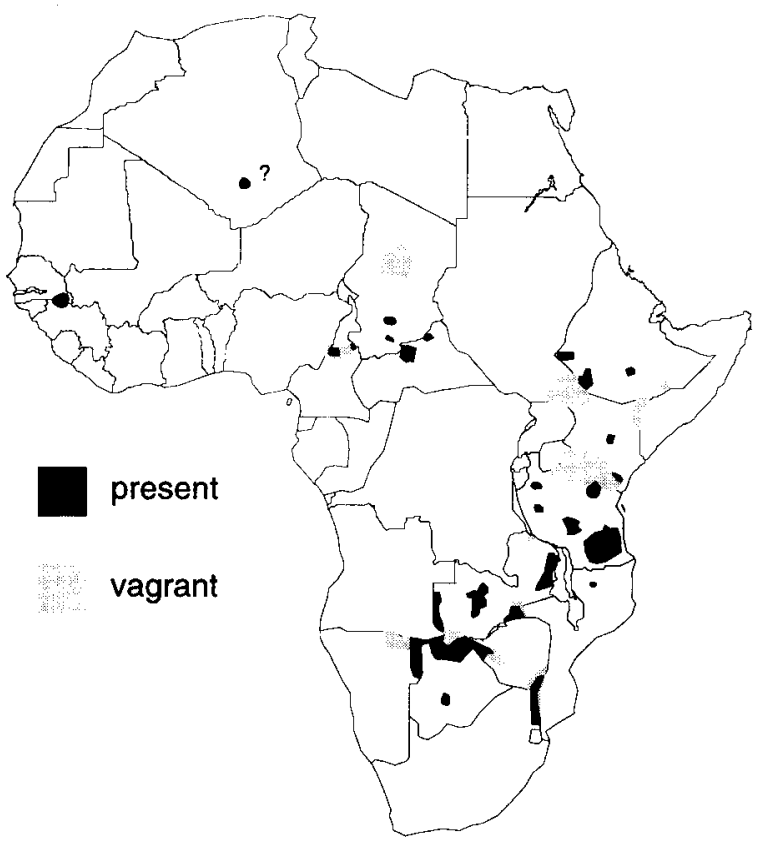

Fig. 1 Distribution of wild dogs c. 1995. Wild dogs' historical distribution covered the majority of sub-Saharan Africa. The population marked with a question mark (?) is known only from unconfirmed reports. Data are from Woodroffe et al. (1997). use smaller areas when they are feeding pups at a den; for example, in Serengeti, home ranges were 50$260 \mathrm{sq} \mathrm{km} \mathrm{during} \mathrm{denning,} \mathrm{but} 1500-2000 \mathrm{sq} \mathrm{km}$ at other times (Burrows, 1995).

Wild dogs are intensely social animals, spending almost all of their time in close association with other pack members. Packs may be as small as a single pair, or number as many as 27 adults and yearlings (Fuller et al., 1992a; Creel \& Creel, 1995). Packs form when small same-sex subgroups-usually siblingsleave their natal groups and join up with other subgroups of the opposite sex. Thus, in newly formed packs the females are closely related to one another, but not to the males, and the males are closely related to one another, but not to the females (Frame et al., 1979; McNutt, 1996; Girman et al., 1997). Young born into such packs may remain there, or disperse as yearlings or young adults to form new packs.

Wild dog packs hunt together, co-operating to bring down large prey (Kuhme, 1965; Creel \& Creel, 1995). They also breed co-operatively: in most packs only the dominant male and female breed, but all pack members care for the pups (Malcolm \& Marten, 1982; Girman et al., 1997). Wild dog litters are extremely large in comparison with other canids, numbering 10-11 pups on average with a maximum of 21 (Fuller et al., 1992a). For this reason, females cannot breed without assistance; the pack, rather than the individual, must therefore be considered the basic unit in the population.

\section{Causes of past decline}

Wild dogs have declined in response to persecution and habitat loss. Like other large predators, they may kill livestock under some circumstances, and have therefore been shot, snared and poisoned in most livestock areas (Woodroffe et al., 1997). Considering wild dogs to be vermin, colonial governments encouraged their eradication; in Zambia, for example, vermin control units killed nearly 5000 wild dogs in the period 1945-59 (Buk, 1994).

Where land has been taken over for farming, wild dogs have been eradicated through a combination of direct persecution and depletion of wild prey. However, they have also disappeared from some regions in which prey and suitable habitat still remain, primarily because they were also persecuted in the name of animal welfare and conservation. Wild dogs kill their prey by tearing it to pieces or disembowelling it (Kuhme, 1965), and this earned them a reputation as cruel and bloodthirsty killers. Game managers' attitudes to them are exemplified by Bere's (1955) report that they '... hunt in packs, killing wantonly far more 
Table 1 Estimated numbers of wild dogs in Africa

\begin{tabular}{|c|c|c|c|}
\hline & \multicolumn{3}{|l|}{ Estimated number of wild dogs } \\
\hline & Associated with protected areas & Outside protected areas & Accuracy of estimates \\
\hline \multicolumn{4}{|l|}{ West Africa } \\
\hline Senegal & 100 & - & Fair \\
\hline \multicolumn{4}{|l|}{ Central Africa } \\
\hline Cameroun & 100 & - & \pm Guess \\
\hline Central African Republic & 150 & - & \pm Guess \\
\hline Tchad & 50 & - & \pm Guess \\
\hline \multicolumn{4}{|l|}{ East Africa } \\
\hline Ethiopia & 100 & 100 & \pm Guess \\
\hline Kenya & 150 & 100 & Fair \\
\hline Tanzania & 1400 & 500 & Good \\
\hline Sudan & - & 100 & \pm Guess \\
\hline \multicolumn{4}{|l|}{ Southern Africa } \\
\hline Botswana & $750^{*}$ & $-*$ & Good \\
\hline Namibia & 100 & 300 & Fair \\
\hline South Africa & 400 & 0 & Good \\
\hline Zambia & 500 & - & Fair \\
\hline Zimbabwe & 500 & 200 & Fair \\
\hline Total & 4300 & 1300 & \\
\hline
\end{tabular}

Countries not listed appear to have no resident wild dog populations.

Most populations 'associated with' protected areas also use surrounding unprotected lands. Population sizes are estimated on the basis of the area occupied, using data on abundance presented in Woodroffe et al. (1997). Adult density was assumed to be $1 / 60 \mathrm{sq} \mathrm{km}$ in areas where wild dogs were reported to be 'common', $1 / 100 \mathrm{sq} \mathrm{km}$ where they were considered 'uncommon', and 1/500 sq km where they were considered 'rare'. All figures are approximate, and estimates of populations outside protected area are particularly uncertain. * Most of Botswana's wild dogs occur in the Okavango region, occupying a network of protected and unprotected land; it is therefore meaningless to separate 'protected' and 'unprotected' populations.

than they need for food, and by methods of the utmost cruelty... it was considered necessary... to shoot wild dogs in order to give the antelope opportunity to develop their optimum numbers...' This belief, that wild dogs suppressed antelope numbers, led to their being persecuted inside national parks and reserves throughout much of Africa. For example, in Zimbabwe up to 600 wild dogs were shot by park staff alone between 1961 and 1975 (Davies, 1992). Elsewhere, persecution of wild dogs was official parks policy as recently as 1979 (Woodroffe et al., 1997), and carried out unofficially as recently as the mid-1980s (Creel \& Creel, 1998). Eradication was remarkably efficient; wild dogs are seldom encountered, but a single marksman can eliminate a whole pack on the few occasions when they are sighted. As Bere (1955) commented, '... only a few of these creatures have had to be destroyed and their number in the parks does not seem to be particularly large...'.

Past declines of wild dogs in several parts of Africa have also been attributed to disease (Stevenson-Hamilton, 1939; Schaller, 1972), but this has not been confirmed.

\section{Possible causes of future decline}

Africa's remaining wild dog populations are highly fragmented and most comprise just a few packs (Woodroffe et al., 1997). Conservation of these populations demands an understanding of the factors likely to cause further decline or local extinction.

\section{Threats to remaining populations}

Population decline will occur when mortality exceeds recruitment, either because birth rates are low, or because mortality of adults or juveniles is high. Population viability analyses indicate that wild dog populations are relatively resilient to changes in the proportion of females breeding, and the mortality of pups, but that small increases in adult mortality can greatly increase the probability of local extinction (Burrows et al., 1994; Woodroffe et al., 1997; Ling, 1998). Analysing the causes of mortality in free-ranging wild dog populations may therefore give an indication of the threats which they face. In Tables 2 and 3 we present data on causes of mortality in five wild dog popula- 
Plate 1 African wild $\operatorname{dog}($ J.R. Ginsberg).

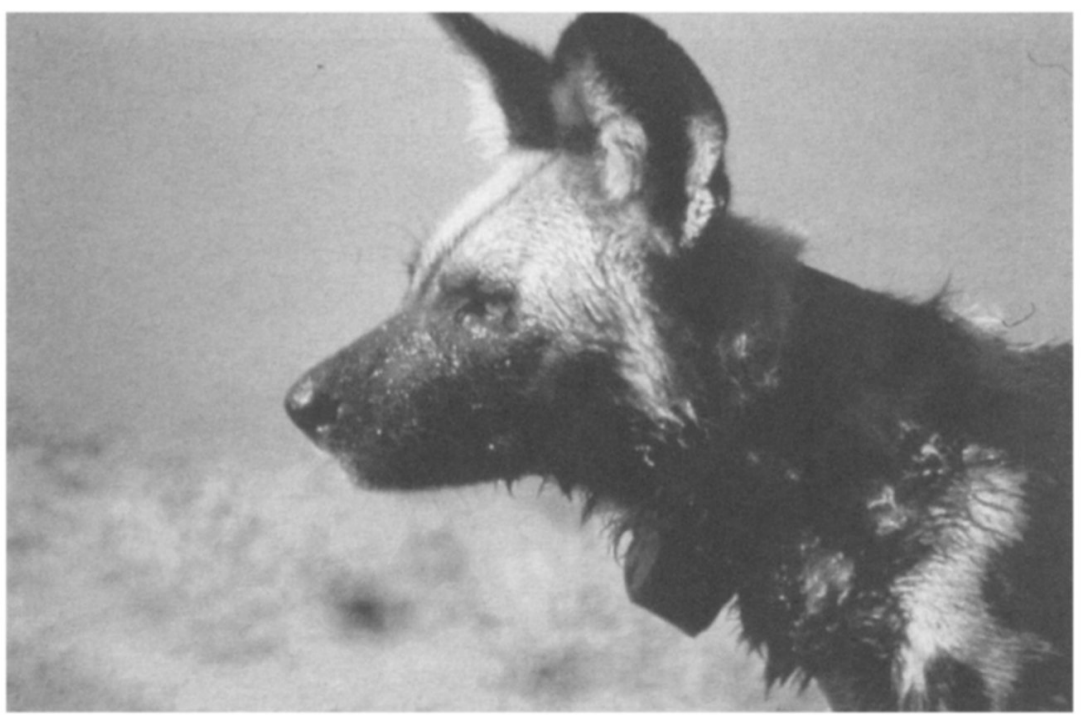

tions in eastern and southern Africa. Some mortality causes may be over-represented in this sample but, because most of the data come from intensive studies involving radio-collared animals, they represent the least biased estimates available.

\section{Lions}

Predation by lions is the single most important cause of natural mortality in free-ranging wild dog populations, accounting for 12 per cent of adult and 31 per cent of pup deaths recorded (Tables 2 and 3). Probably as a result of such predation, wild dog density is negatively correlated with lion density across ecosystems (Creel \& Creel, 1996, 1998). Lion predation also has an indirect effect: within ecosystems, wild dogs avoid areas fre-

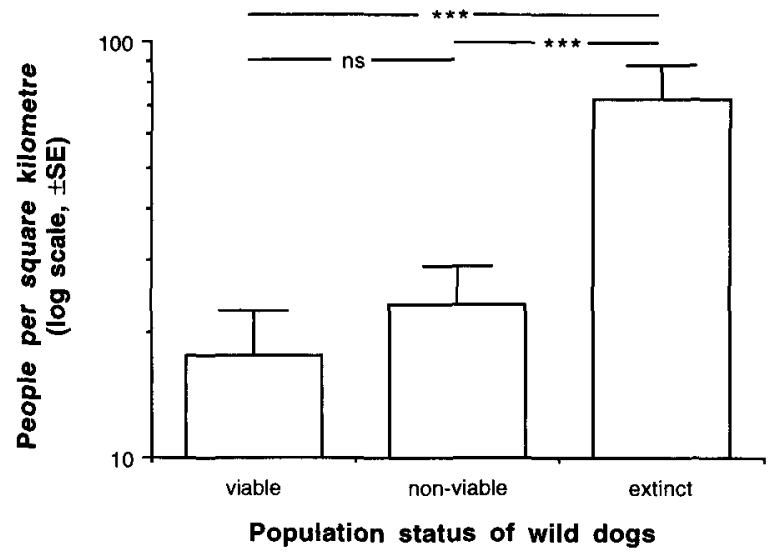

Fig. 2 Human population densities in countries where viable wild dog populations remain, where populations are probably not viable, and where wild dogs have been extirpated. Using log-transformed data, $F_{2,33}=7.63, P<0.005$. Data on wild dogs' status are from Woodroffe et al. (1997), data on human density are from US Census Bureau (1998). quented by lions (Mills \& Gorman, 1997). Because lion density is highest where prey are abundant, wild dogs are forced into areas of low prey density (Mills \& Gorman, 1997). This may have little effect on wild dogs' food intake, because they are very successful hunters everywhere they have been studied (Creel \& Creel, 1998). However, it may be a cause of wild dogs' wideranging behaviour, which brings them into contact with human activity (see below).

\section{Spotted hyaenas}

Predation by spotted hyaenas is much less common than predation by lions, accounting for just 4 per cent of adult and 6 per cent of pup deaths recorded (Tables 2 and 3). The pups killed by hyaenas in Selous were debilitated by infection with anthrax (Creel et al., 1995). A difference in the threat posed by the two larger predators may be reflected in wild $\operatorname{dogs}^{\prime}$ responses to them: they appear to move away from the sound of lions roaring, but ignore or mob hyaenas (Creel \& Creel, 1996).

Although hyaenas cause little mortality directly, loss of prey to hyaenas might be important. When sufficiently numerous, hyaenas may drive wild dog packs away from carcasses (Kruuk, 1972; Fanshawe \& FitzGibbon, 1993); if this occurred frequently, wild dogs' food intake might be severely affected (Gorman et al., 1998). A negative correlation between wild dog and hyaena density across habitats (Creel \& Creel, 1996) has been attributed to such kleptoparasitism (Gorman et al., 1998), but it is not clear whether this relationship is a causal one. Like lions, hyaenas are most abundant in areas of high prey density (Stander, 1991; Mills \& Gorman, 1997); thus hyaena and lion densities are inter-correlated (Creel \& Creel, 1996; Mills \& Gorman, 1997). The relationship between wild dog and hyaena density could 


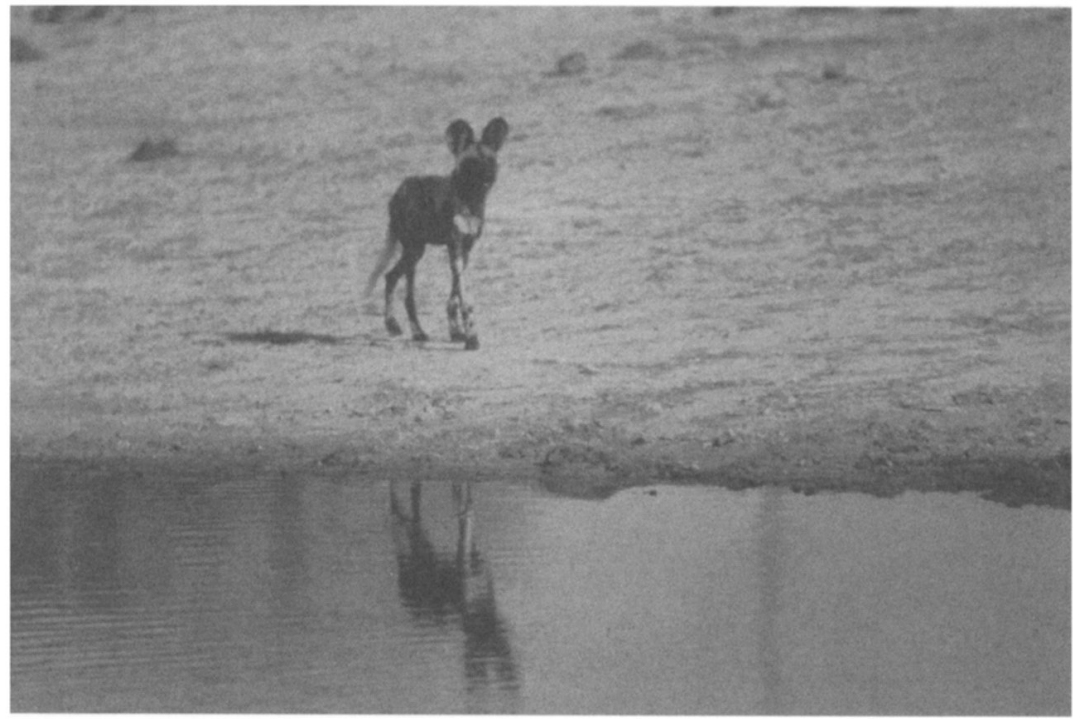

Plate 2 African wild dog (J.R. Ginsberg).

therefore be driven by the impact of lions. Because hyaena kleptoparasitism occurs relatively rarely in most wild dog populations (Mills \& Biggs, 1993; Creel \& Creel, 1996, 1998; J.R.G. unpublished data), it seems likely that lions have a much greater impact.

\section{Disease}

Tables 2 and 3 suggest that disease may be a relatively minor source of mortality, causing just 8 per cent of adult and pup deaths. This picture may not be accurate, however; most of these data were taken from relatively stable populations, while disease mortality is often highly episodic. For example, rabies killed three whole packs in the Serengeti-Masai Mara ecosystem, and may have been responsible for the extinction of the entire population resident in that area (Gascoyne et al., 1993; Burrows, 1995; Kat et al., 1995; Woodroffe et al., 1997). Rabies has also killed wild dogs in the Central African Republic (A. K. Turkalo, pers. comm.) and in Namibia (Scheepers \& Venzke, 1995), and is believed to have been responsible for local declines of wild dogs in Zimbabwe (Childes, 1988).

Infection with canine distemper virus (CDV) may also cause the deaths of entire wild dog packs: it was diagnosed from a pack that died in Chobe National Park, Botswana, in 1994 (Alexander et al., 1996), and was implicated in the loss of five packs around the nearby Moremi Game Reserve the following year ( $\mathrm{J}$. W. McNutt, pers. comm.). Canine distemper has also been reported (but not confirmed) as a cause of death among wild dogs in Serengeti (Schaller, 1972) and Kruger (Reich, 1981). The mortality caused by CDV in wild dogs is unknown, but some animals certainly survive: antibody prevalences may be as high as 100 per cent locally (Table 4).

Anthrax Bacillus anthracis was implicated in wild dogs' decline in the Luangwa Valley, Zambia; during a major anthrax epidemic in 1987, five wild dog carcasses were recovered and anthrax was isolated from four of them (Turnbull et al., 1991; Buk, 1994). In Kruger National Park and Selous Game Reserve, however, wild dogs appear to be affected little by endemic anthrax (Creel et al., 1995; M. G. L. Mills, pers. comm.).

Wild dogs can become infected with a wide variety of other viral, bacterial and protozoan pathogens, including parvovirus, para-influenzavirus, Brucella, Toxoplasma and Neospora (van Heerden et al., 1995; Woodroffe et al., 1997), but the impact of such pathogens remains unclear.

Because wild dog packs seldom encounter one another, highly pathogenic infections such as rabies are likely to kill whole packs before they can be transmitted to other packs. Infection must therefore be acquired from some other reservoir host. There is strong evidence to suggest that domestic dogs provide such a reservoir. Genetic sequencing of rabies viruses from the Serengeti ecosystem showed that wild dogs there died from a rabies strain common in local domestic dogs (Kat et al., 1995). Wherever CDV and parvovirus infections have been found in wild dogs, local domestic dogs have also been infected, usually with higher seroprevalences (Alexander et al., 1993a; Laurenson et al., unpubl. data; J. van Heerden, pers. comm.). Contact with domestic dogs may therefore represent a serious threat. 
Table 2 Causes of adult mortality recorded in free-ranging wild dog populations in: Kruger National Park, South Africa; Moremi Game Reserve and surrounding areas, Botswana; Hwange National Park, Zimbabwe; Selous Game Reserve, Tanzania; and various parts of Zambia (mostly Kafue National Park)

\begin{tabular}{|c|c|c|c|c|c|c|}
\hline & $\begin{array}{l}\text { Kruger* } \\
(n=19) \\
(\%)\end{array}$ & $\begin{array}{l}\text { Moremit } \\
(n=15) \\
(\%)\end{array}$ & $\begin{array}{l}\text { Hwangetł } \\
(n=31) \\
(\%)\end{array}$ & $\begin{array}{l}\text { Seloust } \\
(n=4) \\
(\%)\end{array}$ & $\begin{array}{l}\text { Zambias } \\
(n=36) \\
(\%)\end{array}$ & $\begin{array}{l}\text { Total } \\
(n=105) \\
(\%)\end{array}$ \\
\hline \multicolumn{7}{|l|}{ Natural causes } \\
\hline Lion predation & 26 & 47 & 3 & 0 & 0 & 12 \\
\hline Hyaena predation & 0 & 7 & 10 & 0 & 0 & 4 \\
\hline Other predation & 11 & 7 & 3 & 0 & 3 & 5 \\
\hline Other wild dogs & 16 & 0 & 0 & 50 & 0 & 5 \\
\hline Disease & 0 & 0 & 0 & 0 & 22 & 8 \\
\hline Accident & 0 & 33 & 3 & 0 & 0 & 6 \\
\hline Total & 53 & 94 & 19 & 50 & 25 & 39 \\
\hline \multicolumn{7}{|l|}{ Human causes } \\
\hline Road kill & 5 & 0 & 52 & 0 & 22 & 24 \\
\hline Snared & 21 & 0 & 10 & 25 & 6 & 10 \\
\hline Shot & 21 & 0 & 19 & 0 & 14 & 15 \\
\hline Poisoned & 0 & 0 & 0 & 25 & 33 & 12 \\
\hline Other & 0 & 7 & 0 & 0 & 0 & 1 \\
\hline Total & 47 & 7 & 81 & 50 & 75 & 61 \\
\hline
\end{tabular}

Data from Kruger, Moremi, Hwange and Selous were collected in the course of intensive studies and used radio-telemetry to locate at least some of the carcasses. Figures give the percentages of deaths attributed to each cause.

References: * van Heerden et al. (1995); + Ginsberg et al. (1995); †J.R. Ginsberg (unpublished data); § K. Buk (pers. comm.).

\section{Persecution}

In protected areas, persecution appears to have little impact upon pups, but it is the most important recorded cause of adult mortality: shooting and poisoning together account for 27 per cent of recorded adult deaths (Table 2). Most such mortality occurs when wild dogs range outside reserve borders. Populations living entirely outside protected areas are vulnerable to persecution of both adults and pups, and most have been extirpated (Woodroffe et al., 1997).

Wild dogs are persecuted because they are considered a threat to livestock, especially small stock such as sheep and goats. Few data are available on the economic damage caused by wild dogs, but losses appear to be related to livestock husbandry. In Maasai areas in Kenya, where livestock are accompanied by herders by day and kept in enclosures at night, wild dogs ignore livestock and no losses are reported (Fuller \& Kat, 1990). In contrast, wild dogs do occasionally take calves on ranches in Zimbabwe, where cattle are not protected by herders (Bowler, 1991; Rasmussen, 1996). As in other canids (Ginsberg \& Macdonald, 1990), depredation may be low overall, but a few farms tend to suffer disproportionately and, very occasionally, local losses can be severe (Woodroffe et al., 1997). However, persecution of wild dogs is rarely a direct response to livestock loss: in most of Africa, wild dogs are shot or poisoned whenever they are encountered (Woodroffe et al., 1997).

\section{Snaring}

Capture of wild dogs in snares is an important cause of adult mortality (Table 2). Most are caught accidentally in snares set to catch wild ungulates. Like persecution, snaring is most common on or outside reserve borders but, because of wild dogs' wideranging behaviour, snares set in border areas have an impact on populations even when they inhabit very large protected areas.

\section{Road accidents}

Road accidents are an important cause of death, although the mortality that they cause varies locally. In Hwange National Park, Zimbabwe, road accidents are the single most important cause of recorded mortality for both adults and pups (Tables 2 and 3). Likewise, roads passing through Mikumi National Park, Tanzania, and Kafue National Park, Zambia, are important causes of wild dog mortality (Creel \& Creel, 1993; Buk, 1994; Drews, 1995). Unsurprisingly, road kills do not occur in areas with low human population density, such as northern Botswana and Selous, where traffic is slow-moving or non-existent (Creel \& Creel, 1998). 
Which threats are most likely to cause further local extinctions?

Wild dog populations are under threat from a host of factors, but our data suggest that the causes of their historical decline-habitat loss and persecution-still represent the most serious threats to remaining populations. These two threats interact through wild dogs' low population densities and wide-ranging behaviour. Habitat fragmentation breaks up contiguous populations into smaller units; wild dogs' low density means that even 'fragments' covering thousands of square kilometres support very few individuals. Because small populations are extinction-prone (Soulé, 1987; Berger, 1990), such fragments may be too small to support viable wild dog populations even though other, more abundant, predators may persist.

This effect of small population size is exacerbated by wild dogs' wide-ranging behaviour. More than 60 per cent of the adult mortality recorded in nominally protected populations is directly caused by contact with human activities on or outside reserve borders (Table 2). Wild dogs ranging outside protected areas are vulnerable to persecution, to accidental death in road accidents or snares, and to transmission of disease through contact with domestic dogs. Populations in small reserves are therefore particularly vulnerable-

Table 3 Causes of pup mortality in free-ranging wild dog populations in: Kruger National Park, South Africa; Hwange National Park, Zimbabwe; and Selous Game Reserve, Tanzania

\begin{tabular}{lclll}
\hline & $\begin{array}{l}\text { Kruger* } \\
(n=38) \\
(\%)\end{array}$ & $\begin{array}{l}\text { Hwanget } \\
(n=15) \\
(\%)\end{array}$ & $\begin{array}{l}\text { Selousł } \\
(n=7) \\
(\%)\end{array}$ & $\begin{array}{l}\text { Total } \\
(n=45) \\
(\%)\end{array}$ \\
\hline $\begin{array}{l}\text { Natural causes } \\
\text { Lion predation }\end{array}$ & 37 & $11 \S$ & 43 & 31 \\
Hyaena predation & 0 & $11 \S$ & 29 & 6 \\
Other wild dogs & 50 & $11 \S$ & 0 & 34 \\
Disease & 8 & $0 \S$ & 29 & 8 \\
Total & 95 & $33 \S$ & 100 & 80 \\
Human causes & & & & \\
Road kill & 0 & 47 & 0 & 12 \\
Snared & 5 & 20 & 0 & 8 \\
Total & 5 & 67 & 0 & 20 \\
\hline
\end{tabular}

Figures give the percentages of deaths attributed to each cause. References: * van Heerden et al. (1995); † J. R. Ginsberg (unpublished data); $\ddagger$ Ginsberg et al. (1995).

$\S$ In Hwange, five pups died afer being seen severely wounded by biting. However, since the the cause of injury could not be determined, we attributed these deaths equally to lions, hyaenas and other wild dogs. partly because of their small population size, and partly because the high perimeter : area ratios of small reserves mean that most of the population is exposed to human activity on the reserve borders. Reserves smaller than $c .10,000 \mathrm{sq} \mathrm{km}$ will therefore provide only incomplete protection, as a result of strong edge effects. Such edge effects are an important cause of local extinction among several other carnivore species (Woodroffe \& Ginsberg, 1998).

As well as causing extinction directly, edge effects may influence populations' vulnerability by reducing their ability to recover from perturbation. Population viability analyses indicate that edge effects reduce simulated populations' capacity to recover from occasional whole-pack deaths due to disease, dramatically increasing extinction probabilities in even the largest populations (Ling, 1998).

\section{Priorities for the conservation of Africa's remaining wild dogs}

\section{Landscape management}

Habitat fragmentation and persecution represent the most serious threats to wild dog populations; mitigating these threats therefore has the highest priority for the conservation of Africa's remaining wild dogs. The simplest solution-in biological if not in political terms - is to maintain large areas in which wild dogs are protected from persecution. Maintaining the integrity of existing protected-area complexes, such as Selous, Kruger and Hwange, is vital if wild dog populations are to persist in the long term. Any measures that increase the area of contiguous land available to wild dogs will be beneficial: establishing cross-border parks and buffer zones, and encouraging land use such as game ranching on lands bordering reserves, will all contribute to wild dog conservation. Such landscapelevel management would conserve wild dogs by: (i) maximizing the size of wild dog populations, making them more resilient to perturbations such as disease outbreaks; (ii) ensuring that wild dogs' prey base is maintained; and (iii) minimizing the proportion of packs exposed to human activity by lowering perimeter : area ratios of wildlife areas.

\section{Population management}

The value of very large protected areas for the conservation of wild dogs cannot be over-stated, and maintaining the integrity of such areas has the highest priority for wild dog conservation. In smaller areas, however, various measures could be adopted to reduce the risks of local extinction. 
Table 4 Prevalence of antibodies to rabies and canine distemper virus in free-ranging populations of African wild dogs

\begin{tabular}{llc}
\hline Site & $\begin{array}{l}\text { Seroprevalence } \\
\text { of rabies }(\%)\end{array}$ & $\begin{array}{l}\text { Canine distemper } \\
(\%)\end{array}$ \\
\hline $\begin{array}{l}\text { Masai Mara region, } \\
\text { Kenya }\end{array}$ & $0(18)^{*}$ & $0(12) \dagger$ \\
$\begin{array}{l}\text { Serengeti National Park, } \\
\quad \text { Tanzania }\end{array}$ & $25(12) \ddagger \S$ & $0(16) \mathbb{I}$ \\
$\begin{array}{l}\text { Selous Game Reserve, } \\
\text { Tanzania }\end{array}$ & $0(22)^{* * *}$ & $59(22)^{* *}$ \\
$\begin{array}{l}\text { Moremi Game Reserve, } \\
\text { Botswana }\end{array}$ & - & $50(6)+\dagger$ \\
$\begin{array}{l}\text { Kruger National Park, } \\
\text { South Africa }\end{array}$ & $0(31) \ddagger \ddagger$ & $0(43) \ddagger \ddagger$ \\
$\begin{array}{l}\text { Hluhluwe-Umfolozi } \\
\text { Park, South Africa }\end{array}$ & - & $100(4)+\dagger$ \\
$\begin{array}{l}\text { Tsumkwe District, } \\
\text { Namibia }\end{array}$ & $0(6) \S \S$ & $67(6) \S \S$ \\
Total & $3 \S$ & 22 \\
\hline
\end{tabular}

Figures in brackets give sample sizes.

References: * Alexander et al. (1993b); + Alexander \& Appel

(1994); $\ddagger$ Gascoyne et al. (1993); II M. K. Laurenson (pers. comm.);

${ }^{*}$ Creel et al. (1997); † J. van Heerden (pers. comm.);

㧊 van Heerden et al. (1995); §§ Laurenson et al. (1997).

$\S$ This result may have been a non-specific reaction

(S. Cleaveland, pers. comm.).

\section{Minimizing persecution}

Wild dogs are persecuted primarily because they are considered a threat to livestock. Anecdotal evidence suggests that, like wolves (Boitani, 1992), wild dogs have little impact upon livestock that are herded according to traditional practices (Fuller \& Kat, 1990; S. R. Creel, pers. comm.), but further research is urgently needed. Conservationists must work with farmers to devise husbandry methods that effectively protect livestock from wild dogs, using their findings as the basis for local education campaigns. Managers must approach the problem of persecution with a realistic assessment of the impact that wild dogs may have. Very occasionally, packs or dispersing groups do cause substantial losses; under such circumstances, removing problem animals may be necessary to maintain local support for conservation initiatives (Stander, 1991; Mech, 1995). Alternative approaches, such as compensating farmers for livestock losses, and using aversive conditioning to dissuade predation on domestic animals, have proven largely ineffective in other canid species (Fritts et al., 1992).

\section{Minimizing accidental killings}

Accidental killing of wild dogs in road accidents and in snares is likely to affect population viability. Construction or improvement of roads in and around protected areas should therefore be strictly controlled; this is also a priority for the conservation of other wildlife species. Likewise, snaring in protected areas may be reduced by intensive antipoaching activities. Reducing snaring might also require working with local people to alter demand for bushmeat (Lewis \& Phiri, 1998; Wilkie et al., 1998).

Reflective collars have been devised to protect wild dogs from road accidents and snares, but their effectiveness in reducing mortality has not been evaluated (Mills et al., 1998). Because locating, capturing and collaring wild dogs is time-consuming and expensive, and may involve risks for the immobilized animals (Woodroffe et al., 1997), treating the root causes of accidental killing is preferable to such intensive management (Plate 3).

\section{Managing the threat of disease}

Disease is a serious threat to wild dog populations, but devising disease control strategies combining safety with cost effectiveness has proven problematic. At present, direct vaccination of wild dogs is not a viable

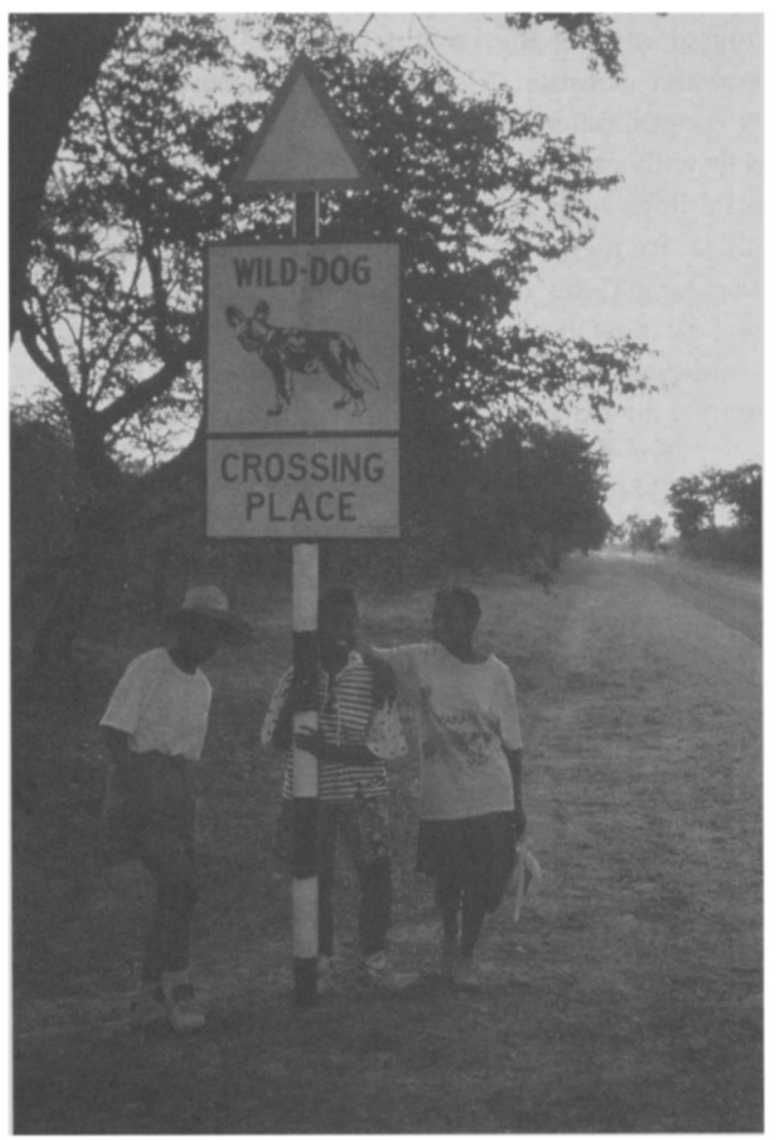

Plate 3 Road sign erected in an effort to reduce the number of wild dogs killed by vehicles on the borders of Hwange National Park, Zimbabwe (J.R. Ginsberg). 
option. Past attempts to protect free-ranging wild dogs from rabies by vaccination have failed, probably because the protocol used was ineffective (Woodroffe et al., 1997). Direct vaccination against CDV may also be inappropriate because no safe, effective vaccine is currently available. More trials are needed in captivity to establish vaccination protocols for both infections. Because such protocols are likely to involve administering multiple doses of vaccine and because wild dog packs are very difficult to locate, vaccination will probably be sustainable only in the smallest areas, or those with extremely open habitat.

As alternatives to direct vaccination, several strategies could be adopted to protect wild dogs by minimizing their contact with infectious domestic dogs. The simplest (and conceivably the most effective) solution would be to limit local populations of domestic dogs. Inside protected areas, domestic dogs need not be tolerated and should be shot on sight. On reserve borders, it might be possible to initiate population control to reduce contact between wild dogs and domestic dogs, and to keep domestic dog populations small enough to avoid the establishment of endemic infections. Where such control is unacceptable, vaccinating domestic dogs might occasionally represent an alternative solution. However, because most domestic dog populations in Africa are semi-feral, breeding freely with rapid population turnover, vaccinating domestic dogs over areas sufficient to protect wild dogs, with a frequency sufficient to maintain vaccination cover, would be extremely labour-intensive. Furthermore, it must be borne in mind that poorly planned or under-funded vaccination programmes have the potential to do more harm than good (Woodroffe, in press). For these reasons, vaccination of domestic dogs is likely to be appropriate only in small areas.

\section{Managing interactions with other predators}

Direct interactions with other, larger, predators have a marked effect upon wild dog populations. Predation by lions is the single most important cause of natural death among adult wild dogs. Furthermore, because avoidance of areas frequented by lions and hyaenas is the most likely explanation for wild dogs' wide-ranging behaviour, interspecific competition might be an indirect cause of wild dogs' exposure to hazards on reserve borders. Despite these effects, control of lion (or hyaena) populations is not a realistic option for wild dog conservation. Lions and hyaenas are important components of African ecosystems, which, through their appeal to tourists, represent a crucial source of revenue for protected areas (Western \& Henry, 1979). Controlling their numbers could therefore be detrimental to local conservation efforts.
Attempts to re-establish wild dog populations by reintroduction might, however, be most successful if they targeted areas with low densities of competing predators (Woodroffe \& Ginsberg, 1999).

\section{Acknowledgements}

Much of the information presented in this paper was collated in the preparation of the IUCN Status Survey and Conservation Action Plan for the African wild dog (Woodroffe et al., 1997). We would like to thank IUCN for permission to cite this information, Kathy Alexander, Sarah Cleaveland, Scott Creel, John Fanshawe, Lory Frame, Todd Fuller, Joseph van Heerden, Nancy Kock, Karen Laurenson, David Macdonald, James Malcolm, Gus Mills, Linda Munson, Phillip Muruthi, Greg Rasmussen, Claudio Sillero-Zubiri, Gavin Thomson and Michael Woodford for comments on sections of the action plan, and Sarah Durant and an anonymous reviewer for comments on the manuscript.

\section{References}

Alexander, K. \& Appel, M. (1994) African wild dogs (Lycaon pictus) endangered by a canine distemper epizootic among domestic dogs near the Masai Mara National Reserve, Kenya. Journal of Wildlife Diseases, 30, 481-485.

Alexander, K.A., Smith, J.S., Macharia, M.J. \& King, A.A. (1993a) Serologic survey for selected microbial pathogens in African wild dogs (Lycaon pictus) and sympatric domestic dogs (Canis familiaris) in Masai Mara, Kenya. Journal of Zoo And Wildlife Medicine, 24, 140-144.

Alexander, K.A., Smith, J.S., Macharia, M.J. \& King, A.A. (1993b) Rabies in the Masai Mara, Kenya: a preliminary report. Onderstepoort Journal of Veterinary Research, 60, 411-414.

Alexander, K.A., Kat, P.W., Munson, L.A., Kalake, A. \& Appel, M.J.G. (1996) Canine distemper-related mortality among wild dogs (Lycaon pictus) in Chobe National Park, Botswana. Journal of Zoo andWildlife Medicine, 27, 426-427.

Bere, R.M. (1955) The African wild dog. Oryx, 3, 180-182.

Berger, J. (1990) Persistence of different-sized populations: an empirical assessment of rapid extinctions in bighorn sheep. Conservation Biology, 4, 91-98.

Boitani, L. (1992) Wolf research and conservation in Italy. Biological Conservation, 61, 125-132.

Bowler, M. (1991) Implications of large predator management on commercial ranchland in Zimbabwe. MSc thesis, University of Zimbabwe.

Buk, K.G. (1994) Conservation Status of Wild Dog in Zambia. Preliminary report. Zambia Wild Dog Project, PO Box 60086, Livingstone, Zambia.

Burrows, R. (1995) Demographic changes and social consequences in wild dogs 1964-1992. In Serengeti II: Research, Management, and Conservation of an Ecosystem. (eds A. R. E. Sinclair and P. Arcese), pp. 400-420. Chicago University Press, Chicago. 
Burrows, R., Hofer, H. \& East, M.L. (1994) Demography, extinction and intervention in a small population: the case of the Serengeti wild dogs. Proceedings of the Royal Society of London B, 256, 281-292.

Childes, S.L. (1988) The status and distribution of Lycaon pictus in Zimbabwe. Biological Conservation, 44, 301-316.

Creel, S.R. \& Creel, N.M. (1993) Conservation of African Wild Dogs (Lycaon pictus): a Photographic Census in Mikumi National Park. Unpublished report, Tanzania National Parks, Dar es Salaam.

Creel, S. \& Creel, N.M. (1995) Communal hunting and pack size in African wild dogs, Lycaon pictus. Animal Behaviour, 50, 1325-1339.

Creel, S.R. \& Creel, N.M. (1996) Limitation of African wild dogs by competition with larger carnivores. Conservation Biology, 10, 1-15.

Creel, S. \& Creel, N.M. (1998) Six ecological factors that may limit African wild dogs, Lycaon pictus. Animal Conservation, 1, 1-9.

Creel, S., Creel, N.M., Munson, L., Sanderlin, D. \& Appel, M.J.G. (1997) Serosurvey for selected viral diseases and demography of African wild dogs in Tanzania. Journal of Wildlife Diseases, 33, 823-832.

Creel, S., Creel, N.M., Matovelo, J.A., Mtambo, M.M.A., Batamuzi, E.K. \& Cooper, J.E. (1995) The effects of anthrax on endangered African wild dogs (Lycaon pictus). Journal of Zoology, 236, 199-209.

Cumming, M., du Toit, D.H. \& Stuart, S.N. (1990) African Elephants and Rhinos: Status Survey and Conservation Action Plan. IUCN, Gland, Switzerland.

Davies, C. (1992) Status of Lycaon in Zimbabwe. Proceedings of a Workshop on the Conservation \& Recovery of the African Wild Dog, Lycaon pictus, Arusha, Tanzania. Unpublished report available from Canid Specialist Group, Department of Zoology, University of Oxford, UK.

Drews, C. (1995) Road kills of animals by public traffic in Mikumi National Park, Tanzania, with notes on baboon mortality. African Journal of Ecology, 33, 89-100.

Fanshawe, J.H. (1989) Serengeti's painted wolves. Natural History, March, 56-67.

Fanshawe, J.H. \& FitzGibbon, C.D. (1993) Factors influencing the hunting success of an African wild dog pack. Animal Behaviour, 45, 479-490.

Fanshawe, J.H., Frame, L.H. \& Ginsberg, J.R. (1991) The wild dog-Africa's vanishing carnivore. Oryx, 25, 137-146.

Frame, L.H., Malcolm, J.R., Frame, G.W. \& van Lawick, H. (1979) Social organization of African wild dogs (Lycaon pictus) on the Serengeti Plains. Zeitschrift für Tierpsychologie, 50, 225-249.

Fritts, S.H., Paul, W.J., Mech, L.D. \& Scott, D.P. (1992) Trends and Management of Wolf-Livestock Conflicts in Minnesota. Resource Publication 181. US Fish \& Wildlife Service.

Fuller, T.K. \& Kat, P.W. (1990) Movements, activity, and prey relationships of African wild dogs (Lycaon pictus) near Aitong, south-western Kenya. African Journal of Ecology, 28, 330-350.

Fuller, T.K., Mills, M.G.L., Borner, M., Laurenson, K. \& Kat, P.W. (1992a) Population dynamics of African wild dogs. In Wildlife 2001: Populations (eds D. R. McCullough and H. Barrett), pp. 1125-1138. Elsevier Science Publishers, London.

Fuller, T.K., Mills, M.G.L., Borner, M., Laurenson, K. \& Kat,
P.W. (1992b) Long distance dispersal by African wild dogs in East and South Africa. Journal of African Zoology, 106, 535-537.

Gascoyne, S.C., King, A.A., Laurenson, M.K., Borner, M., Schildger, B. \& Barrat, J. (1993) Aspects of rabies infection and control in the conservation of the African wild dog (Lycaon pictus) in the Serengeti region, Tanzania. Onderstepoort Journal of Veterinary Research, 60 , 415-420.

Ginsberg, J.R. \& Macdonald, D.W. (1990) Foxes, Wolves, Jackals and Dogs: An Action Plan for the Conservation of Canids. IUCN, Gland, Switzerland.

Ginsberg, J.R., Alexander, K.A., Creel, S., Kat, P.W., McNutt, J.W. \& Mills, M.G.L. (1995) Handling and survivorship of African wild dog (Lycaon pictus) in five ecosystems. Conservation Biology, 9, 665-674.

Girman, D., Mills, M.G.L., Geffen, E. \& Wayne, R.K. (1997) A molecular genetic analysis of social structure, dispersal, and interpack relations of the African wild dog (Lycaon pictus). Behavioural Ecology and Sociobiology, 40, 187-198.

Gittleman, J.L. \& Harvey, P.H. (1982) Carnivore home range size, metabolic needs and ecology. Behavioural Ecology and Sociobiology, 10, 57-63.

Gorman, M.L., Mills, M.G., Raath, J.P. \& Speakman, J.R. (1998) High hunting costs make African wild dogs vulnerable to kleptoparasitism by hyaenas. Nature, 391, $479-481$.

van Heerden, J., Mills, M.G.L., van Vuuren, M.J., Kelly, P.J. \& Dreyer, M.J. (1995) An investigation into the health status and diseases of wild dogs (Lycaon pictus) in the Kruger National Park. Journal of the South African Veterinary Medical Association, 66, 18-27.

IUCN (1996) 1996 IUCN Red List of Threatened Animals. IUCN, Gland, Switzerland.

Kat, P.W., Alexander, K.A., Smith, J.S. \& Munson, L. (1995) Rabies and African wild dogs in Kenya. Proceedings of the Royal Society of London B, 262, 229-233.

Kruuk, H. (1972) The Spotted Hyaena. Chicago University Press, Chicago.

Kuhme, W.D. (1965) Communal food distribution and division of labour in African hunting dogs. Nature, 205, 442-444.

Laurenson, K., Esterhuysen, J., Stander, P. \& van Heerden, J. (1997) Aspects of rabies epidemiology in Tsumkwe District, Namibia. Onderstepoort Journal of Veterinary Research, 64, 39-45.

Lewis, D.M. \& Phiri, A. (1998) Wildlife snaring-an indicator of community response to a community-based conservation project. Oryx, 32, 111-121.

Ling, S. (1998) Edge effects and extinction - population viability analysis for the African wild dog, Lycaon pictus. BA project, University of Cambridge.

Maddock, A.H. \& Mills, M.G.L. (1994) Population characteristics of the African wild dogs Lycaon pictus in the eastern Transvaal lowveld, South Africa, as revealed through photographic records. Biological Conservation, 67, $57-62$.

Malcolm, J.R. \& Marten, K. (1982) Natural selection and the communal rearing of pups in African wild dogs (Lycaon pictus). Behavioural Ecology and Sociobiology, 10, 1-13.

McNutt, J.W. (1996) Sex-biased dispersal in African wild dogs, Lycaon pictus. Animal Behaviour, 52, 1067-1077. 
Mech, L.D. (1995) The challenge and opportunity of recovering wolf populations. Conservation Biology, 9, 270-278

Mills, M.G.L. \& Biggs, H.C. (1993) Prey apportionment and related ecological relationships between large carnivores in Kruger National Park. Symposia of the Zoological Society of London, 65, 253-268.

Mills, M.G.L. \& Gorman, M.L. (1997) Factors affecting the density and distribution of wild dogs in the Kruger National Park. Conservation Biology, 11, 1397-1406.

Mills, M.G.L., Ellis, S., Woodroffe, R., Maddock, A., Stander, P. Rasmussen, G. et al. (1998) Population and Habitat Viability Assessment for the African Wild Dog (Lycaon pictus) in Southern Africa. IUCN/SSC Conservation Breeding Specialist Group, Apple Valley MN, USA.

Rasmussen, G.S.A. (1996) A Case Study of Livestock Predation by the Painted Hunting Dog Lycaon pictus in a Cattle Ranching Area. Unpublished report. Natural History Museum, Bulawayo.

Reich, A. (1981) The behaviour and ecology of the African wild dog (Lycaon pictus) in the Kruger National Park. PhD thesis, Yale University.

Said, M.Y., Chunge, R.N., Craig, G.C., Thouless, C.R., Barnes, R.F.W. \& Dublin, H.T. (1995) African Elephant Database. IUCN/SSC, Gland, Switzerland.

Schaller, G.B. (1972) The Serengeti Lion: a Study of Predator-Prey Relations. University of Chicago Press, Chicago.

Scheepers, J.L. \& Venzke, K.A.E. (1995) Attempts to reintroduce African wild dogs Lycaon pictus into Etosha National Park, Namibia. South African Journal of Wildlife Research, 25, 138-140.

Soulé, M. (1987) Viable Populations for Conservation Cambridge University Press, Cambridge.

Stander, P.E. (1991) Aspects of the ecology and scientific management of large carnivores in sub-Saharan Africa. M. Phil. thesis, University of Cambridge.

Stevenson-Hamilton, J. (1939) The health of wild animals. Journal of the South African Veterinary Medical Association, 10, 56-64.

Turnbull, P.C.B., Bell, R.H.V., Saigawa, K., Munyenyembe, F.E.C., Mulenya, C.K. \& Makal, L.H.C. (1991) Anthrax in wildlife in the Luangwa valley, Zambia. Veterinary Record, 128, 399-403.

US Census Bureau (1998) International Data Base. http://www.census.gov/ipc/www/idbprint.html

Western, D. \& Henry, W. (1979) Economics and conservation in third world national parks. Bioscience, 29, 2764-2769.

Wilkie, D.S., Curran, B., Tshombe, R. \& Morelli, G.A. (1998) Managing bushmeat hunting in Okapi Wildlife Reserve, Democratic Republic of Congo. Oryx , 32, 131-144.

Woodroffe, R. (in press). Managing disease risks to wild mammals. Animal Conservation.

Woodroffe, R. \& Ginsberg, J.R. (1998) Edge effects and the extinction of populations inside protected areas. Science, 280, 2126-2128.

Woodroffe, R. \& Ginsberg, J.R. (1999) Conserving the African wild dog, Lycaon pictus. II. Is there a role for reintroduction? Oryx, 33, 145-153.

Woodroffe, R., Ginsberg, J.R. \& Macdonald, D.W. (1997) The African Wild Dog: Status Survey and Conservation Action Plan. IUCN, Gland, Switzerland.

\section{Biosketches}

Rosie Woodroffe is a lecturer in Conservation Biology at the University of Warwick, UK. Much of her research focuses on the resolution of conflict between predators and people, encompassing both conservation biology and wildlife management. She and Joshua Ginsberg are co-authors of The African Wild Dog: Status Survey and Conservation Action Plan published by IUCN.

Joshua Ginsberg carried out a 5-year field study of wild dogs in and around Hwange National Park, Zimbabwe, before becoming Director of the Asia Program for the Wildlife Conservation Society, based in New York. He oversees 110 projects in 15 Asian countries on topics ranging from the taxonomy and ecology of frogs in the highlands of Papua New Guinea to community-based approaches to conservation in Laos. 